\title{
MAŁGORZATA LASKOWSKA
}

\section{Media i teologia. Kierunki badań teologicznych w ujęciu Magisterium Kościoła}

\author{
Nie jesteśmy tu po to, aby obchodzić urodziny Soboru, \\ ale by przyjrzeć się jego wplywowi na rozwój teologii. \\ Sobór Watykański II jest nadal aktualny. \\ ks. Ángel Galindo
}

W 2013 roku minęło pięćdziesiąt lat od ogłoszenia dekretu o środkach społecznego przekazywania myśli „Inter mirifica” (4 grudnia 1963 r.). Ponieważ Sobór Watykański II był tym przełomowym w podejściu Kościoła do mediów, rocznica ta budzi wiele pytań, odnoszących się szczególnie do współczesnych środków przekazu, wyznacznikiem których jest interaktywność i cyfrowość. Krótko po wydaniu wspomnianego dekretu zaczęto zastanawiać się, co on oznacza dla środowiska mediów, a także dla Kościoła - jak jego wytyczne zostaną wcielone w życie. Dokument ten zapoczątkował pogłębioną teologiczną refleksję nad mediami w kolejnych dokumentach, zwłaszcza tych wydanych przez Papieską Radę ds. Środków Społecznego Przekazu: „Communio et progressio” (1971), „Pornografia i przemoc w środkach przekazu: odpowiedź duszpasterska” (1989), „Aetatis novae” (1992), „Etyka w reklamie” (1997), „Etyka w środkach społecznego przekazu” (2000), „Etyka w Internecie” (2002), „Kościół a Internet” $(2002)^{1}$. Cennym źródłem nauczania Kościoła o mediach są wydawane od 1967 roku orędzia na Światowy Dzień Środków Społecznego Przekazu.

Małgorzata L A S K O W S K A, dr, adiunkt, Katedra Teorii, Aksjologii i Prawa Mediów, Instytut Edukacji Medialnej i Dziennikarstwa, Wydział Teologiczny Uniwersytetu Kard. Stefana Wyszyńskiego w Warszawie, m.laskowska@uksw.edu.pl

${ }^{1}$ Przed Soborem Watykańskim II środki społecznego przekazu nie są jeszcze tak powszechnie dostępne. Głównie prasa jest dobrze umiejscowiona w przestrzeni społecznej, radio zaś, a szczególnie telewizja są w fazie rozwoju. Stąd też dokumentów na ich temat nie ma wiele, aczkol- 


\section{Uwagi metodologiczne}

Celem prezentowanego artykułu jest poszukiwanie odpowiedzi na pytania o wpływ dokumentu „Inter mirifica”, oraz kolejnych po nim, na teologię. By bliżej przyjrzeć się postawionemu w pracy problemowi, postawiono pytania szczegółowe: W jakim stopniu teologowie podjęli refleksję nad dokumentem bezpośrednio po Soborze? Jaki jest stan wiedzy, stan badań w zakresie teologii środków społecznego przekazu, teologii komunikacji w Polsce? Jak należy rozumieć teologię środków społecznego przekazu? Jakich pojęć - dla zobrazowania jej właściwego przedmiotu - lepiej używać - teologia mediów, teologia środków społecznego komunikowania, teologia komunikacji? Jakie kierunki badań w tym zakresie proponuje Kościół? Jakie wyzwania ten pięćdziesięcioletni dokument stawia przed współczesną teologią?

Autorka, podejmując się opracowania zaproponowanej tematyki, kierowała się również intencją rozbudzenia dyskusji i debaty nad tożsamością, szczególnie naukową, teologii środków społecznego przekazu. Jako młody pracownik naukowy liczy bowiem na głosy, zainteresowanie ze strony doświadczonego środowiska teologów w tym zakresie, zwłaszcza w obszarze zagadnień metodologicznych, by przygotować grunt $\mathrm{w}$ teologii do coraz odważniejszego podjęcia tematyki związanej z nowymi mediami oraz technologia, rozwijającą się w tempie błyskawicznym.

Powodem zabrania głosu w kwestii naukowej tożsamości teologii mediów oraz komunikacji jest także fakt, iż powstaje $\mathrm{w}$ tym obszarze coraz więcej prac dyplomowych na polskich uniwersytetach. Na etapie ich przygotowania pojawiają istotne pytania, najczęściej natury metodologicznej. Jeśli praca powstaje na seminarium (bądź też ze specjalności) teologii środków społecznego przekazu, to:

- co jest źródłem? (czy głównie dokumenty Kościoła o mediach?);

- jakie metody badawcze zastosować? (na ile można czerpać z metod wypracowanych przez inne specjalności teologiczne, np. z paradygmatu analizy teologii pastoralnej?);

- na jakie pytanie odpowiada teologia mediów, teologia komunikacji? (ustalenie tego pozwoli wypracować metodę badawczą) itd.

Pytań tych pojawia się znacznie więcej. Ich zadaniem jest jedynie zasygnalizowanie problemu.

wiek wypowiedzi te wpisują się w ewolucję stanowiska Kościoła względem mediów. Najobszerniejszym dokumentem na temat ówczesnych mediów jest „Vigilanti cura” P i u s a X I z 1936 roku o widowiskach kinematograficznych. Na uwagę zasługuję także encyklika Piusa XII „Miranda prorsus" z 1957 roku o filmie, radiu i telewizji. 
$\mathrm{W}$ prezentowanym artykule zgłębiono najpierw zagadnienie mediów jako przedmiotu interdyscyplinarnego, $\mathrm{w}$ tym ze szczególnym uwzględnieniem nauk teologicznych. Następnie, w celu nakreślenia naukowej tożsamości teologii środków społecznego przekazu, przeanalizowano jej definicję, źródła, stan badań w Polsce i w końcu - na podstawie nauczania Kościoła - kierunki badań naukowych, proponowanych $\mathrm{w}$ obszarze teologii mediów. Taka ukierunkowana analiza zagadnienia $\mathrm{w}$ związku z podjętym tematem ma charakter otwarty i stanowi przyczynek do dyskusji.

\section{Media przedmiotem badań interdyscyplinarnych}

Media i komunikacja są tak pojemnymi naukowo zagadnieniami, iż znajdują się w obszarze badań wielu dyscyplin: społecznych (socjologia, pedagogika, psychologia, prawo, stosunki międzynarodowe, nauki o mediach ${ }^{2}$ ), humanistycznych (kulturoznawstwo, nauki o zarządzaniu, ale także filozofia ${ }^{3}$ i teologia). W kontekście podjętego tematu warto na dłużej zatrzymać się przy teologii, bowiem od momentu wydania „Inter mirifica” media i zagadnienia pochodne znalazły się w obszarze jej zainteresowań.

Tematyka medialna wpisuje się przede wszystkim w obszar badawczy teologii pastoralnej, inaczej też określanej teologią praktyczną ${ }^{4}$. Rozumiana jest ona jako nauka teologiczna zmierzajaca do wypracowania - w świetle Objawienia Bożego i analizy teraźniejszej sytuacji Kościoła - zasad i dyrektyw pastoralnych, wedlug których Kościót urzeczywistnia siebie i realizuje pośrednictwo zbawcze $d_{z i s i a j}{ }^{5}$. W aktualną rzeczywistość Kościoła wpisują się także środki społeczne-

\footnotetext{
2 Jest to nowa dyscyplina powołana decyzją Ministerstwa Nauki i Szkolnictwa Wyższego dn. 8 sierpnia 2011 r. O jej tożsamości metodologicznej debatowano m.in. podczas konferencji „Tożsamość nauk o mediach" zorganizowanej przez Instytut Dziennikarstwa Uniwersytetu Warszawskiego w dn. 22-23 czerwca 2012 r. Zob. T. G a c k o w s k i: Konferencja „,Tożsamość nauk o mediach”, czyli medioznawcza polifonia starej-nowej dyscypliny naukowej. „Studia Medioznawcze”. T. 2: 2012 s. 11-27; W. S o ń c z y k: Tożsamość nauk o mediach (refleksje po konferencji). „Studia Medioznawcze”. T: 2: 2012 s. 28-37.

${ }^{3}$ Zob. R. M is z c zy ński, A. T a rn o pols ki: Filozofia i mass media. „Diamestros”. T. 4: 2005 s. 12-28. M. D r o ż d ż filozofię mediów interpretuje jako „przestrzeń wyjaśnień antropologiczno-aksjologicznych uwarunkowań nowych mediów. Ma ona za zadanie pokazać koewolucję mediów i społeczeństwa w globalnej przestrzeni technokultury. Przedmiotem filozofii mediów staje się zarówno „medium”, jak i „media”, rozumiane nie tyle jako różnego rodzaju techniczne środki przekazu, ile jako pragmatyczne faktory, zasady modelowania i porządkowania świata ludzkiej komunikacji oraz przede wszystkim jako przestrzeń osobowych działań medialnokomunikacyjnych". M. D r o żd ż: Osoba i media. Personalistyczny paradygmat etyki mediów. Tarnów 2005 s. 19.

${ }^{4}$ Więcej na temat definicji w: B. M i e rzw ińs ki: Teologia pastoralna na ATK-UKSW. „Warszawskie Studia Pastoralne”. T. 10: 2010 s. 11-18.

${ }_{5}$ R. K a miński: Tożsamość współczesnej teologii pastoralnej. „Roczniki PastoralnoKatechetyczne”. T. 4: 2012 s. 21-36.
} 
go przekazu, mające silne oddziaływanie na człowieka, a zatem także na jego życie moralne, religijne i duchowe. Nie bez znaczenia dla współczesnego Kościoła są także nowe formy komunikacji międzyludzkiej, do której możemy zaliczyć przede wszystkim tzw. komunikację zapośredniczona, której podstawowym narzędziem jest Internet. Dla teologa (także etyka, socjologa) wypływa z niej zasadniczy wniosek - w przestrzeni wirtualnej coraz więcej jest człowieka ${ }^{6}$.

W związku z powyższym w teologii pastoralnej można postawić następujące pytanie: W jaki sposób media mogą być wykorzystane do urzeczywistniania się Kościoła tu na ziemi? Szczegółowa problematyka badawcza skupia się zatem wokół zastosowania środków społecznego przekazu w działalności duszpasterskiej. Wielu pastoralistów podejmuje zagadnienia związane $\mathrm{z}$ mediami ${ }^{7}$, traktując głównie media jako narzędzie ewangelizacji ${ }^{8}$. Środki społecznego przekazu rozumiane jako narzędzia ewangelizacji, a także duszpasterstwa skłaniają teologię pastoralną do potraktowania tego tematu z perspektywy interdyscyplinarnej. Można bowiem wiele wynieść $\mathrm{z}$ nauk humanistycznych oraz społecznych, zwłaszcza na etapie analizy obecnej sytuacji Kościoła ${ }^{9}$. Pomocna w tym względzie jest szczególnie socjologia, która podsuwa liczne narzędzia badań empirycznych, umożliwiające bliższą i dokładniejszą obserwację zjawisk społecznych i zbiorowości ${ }^{10}$. Na badaniach empirycznych teologia pastoralna wiele zyskuje, stanowi podstawy do ewentualnych zmian $\mathrm{w}$ działaniach duszpasterskich.

Środki społecznego przekazu są także przedmiotem badań teologii moralnej. W jej perspektywie ocenia się nie tyle media, a działania człowieka za ich pośrednictwem. Zadaniem bowiem teologii moralnej jest wypracowanie norm po-

${ }^{6}$ Zob. M. L a s k o w s k a: Nowe media - nowa etyka? W: Nowe media, ale nowe czy stare problemy? Red. J. H aj d a s z. Poznań 2011 s. 97-116; T a ż: Komunikacja za pomoca social media - możliwości i zagrożenia. Zarys problematyki. W: Komunikacja - (po)rozumienie - obecność społeczna. Red. M. B i e d r o ń, M. W a w r z a k - C h o d a c z e k. Toruń 2012 s. 29-41.

Komunikacja wyzwaniem dla Kościoła. Red. T. Z a s ę p a. Lublin 2004; A. D r a g u 1 a: Eucharystia zmediatyzowna. Teologiczno-pastoralna interpretacja transmisji Mszy Świętej w radiu $i$ telewizji. Zielona Góra 2009.

${ }^{8}$ A. B a c z y ń s ki: Przekaz i formacja wiary przez media. W: Teologia pastoralna naukq w stużbie nowej ewangelizacji. Red: Cz. K r a k ow i a k, W. P r z y g o d a, A. K i c iń s k i. Lublin 2010 s. 105-121; W. Ś m i g i e 1: Internet jako narzędzie działalności pastoralnej Kościoła. „Studia Pelplińskie". T. 33: 2002 s. 579-587.

${ }^{9}$ Zob. Paradygmat analizy teologii pastoralnej w: R. K a m i ń s k i: Z metodologii teologii pastoralnej. „Studia Nauk Teologicznych PAN” T. 2: 2007 s. 243-246.

10 Problematykę współpracy teologii pastoralnej z socjologią podejmują m.in. ks. dr T. W i e le bski oraz dr M.J. T u tak z Uniwersytetu Kard. Stefana Wyszyńskiego w Warszawie. Zob. T. W i e l e b s k i, M.J. T u t a k: Diagnoza i prognoza jako narzędzie dialogu teologii pastoralnej z socjologiq na przykładzie świętowania niedzieli i starzenia się spoleczeństwa $w$ Polsce. „Teologia Praktyczna”. T. 11: 2010 s. 27-50; T. W i e l e b s k i, M.J. T u t a k: Analiza jako metoda wspótpracy teologii pastoralnej i socjologii na przykładzie badań ukazujacych przeżywanie niedzieli przez młodzież. „Teologia Praktyczna”. T. 12:2011 s. 169-193; M.J. T u t a k: Relacja między teologia pastoralnq a socjologiq religii. „Warszawskie Studia Pastoralne”. T. 10: 2009 s. 30-39. 
stępowania człowieka, albo innymi słowy odpowiedź na pytanie, co powinien człowiek czynić i czego zaniechać, jeżeli nie tylko ma zachować swoja ludzka godność i osiagnać jak najwyższy stopień ludzkiej doskonatości, ale także jeżeli ma sie zbawić ${ }^{11}$. Moralista zanim dokona oceny moralnej zjawiska, bądź też ludzkiego działania, musi to zjawisko, bądź też konkretną rzeczywistość dogłębnie poznać. Narzędzia ku temu posiadają wspomniane już nauki humanistyczne oraz społeczne. Jak zaznacza P. Góralczyk, bytoby (...) oznakq nieliczenia się z rzeczywistościa, gdyby moralista stale tracit z pola widzenia to wszystko, co podpada pod kompetencje nauk empirycznych ${ }^{12}$. Tę współpracę najwyraźniej dostrzega się na przykładzie tematów bioetycznych, ale także tych dotyczących mediów. W tym przypadku problemy badawcze skupiałby się na ocenie moralnej użytkowania (działań, czynów, decyzji użytkownika) mediów.

Komunikacją zainteresowana jest również teologia dogmatyczna rozumiana jako nauka realistyczna, gdyż traktuje o rzeczywistości religijnej, o Bogu żywym, o człowieku i o świecie, a nie jedynie o języku religijnym, o ideach religijnych, o samej wierze czy o zdaniach wiary i Biblii. Jej fundamentalnym źródlem w rozumieniu katolickim jest objawienie Boże ${ }^{13}$. Na kanwie jej dziedziny teologicznej analizuje się i rozważa tajemnicę komunikacji Trzech Osób Boskich. Relację tę, fundamentem której jest miłość, odnosi się do stosunków międzyludzkich ${ }^{14}$. W tym znaczeniu można podać również interpretację T. Chromika, który zaznacza, iż teologia środków społecznego przekazu została zidentyfikowana z teologia posłannictwa Chrystusa i Kościoła, w którym chodzi nie tylko o przekazanie swej idei, ale przede wszystkim o oddanie siebie, o zakomunikowanie swej osoby jako daru miłości ${ }^{15}$. Teologia dogmatyczna zwraca zatem szczególną uwagę na chrystologiczny aspekt komunikacji. Szczególnie cenne na ten temat uwagi można odnaleźć w dokumencie „Communio et pogressio”. Na przykładzie stylu oraz sposobu komunikowania się Chrystusa Kościół ukazuje, iż komunikacja to nie tylko przekazywanie myśli, idei, ale to przede wszystkim dzielenie się miłością. Dał się poznać jako doskonały „Głosiciel”, mówiąc językiem i gestem człowie$\mathrm{ka}^{16}$. Dziś w pełni zaś „komunikuje” siebie podczas ofiary eucharystycznej.

${ }^{11}$ J. M a j k a: Metodologia nauk teologicznych. Wrocław 1981 s. 204.

${ }^{12}$ P. G ó r a l c z y k: Teologia moralna - poszukiwanie tożsamości metodologicznej. „Studia Nauk Teologicznych”. T. 2: 2007 s. 199.

${ }^{13}$ Cz. B a r t n i k: Metodologia teologii dogmatycznej. „Studia Nauk Teologicznych”. T. 2: 2007 s. 165.

${ }^{14}$ Zob. M. J a g od z ińs ki: Teoria komunikacyjnego działania w nauce o Trójcy Świętej. „Studia Koszalińsko-Kołobrzeskie”. T. 15: 2010 s. 47-69.

${ }^{15}$ T. Ch ro mi k: Środki społecznego przekazu na tle duszpasterskich zadań i potrzeb Kościoła. W: Kościól a kultura masowa. Red. F. A d a m s k i. Kraków 1984 s. 82.

${ }^{16}$ W kontekście chrystologii w nurcie teologii komunikacji pisał A. J e ż w: „Jezus Chrystus w kontekście ludzkiej komunikacji” (Tarnów 2002). 
W tym kontekście można zauważyć, iż Eucharystia jest wyrazem pełnego zjednoczenia się Boga i człowieka, którego fundamentem jest Duch Święty ${ }^{17}$.

Przestrzeń medialna i komunikacyjna człowieka, czyli jego mediosfera przynależy także do obszaru badawczego teologii fundamentalnej. Przedmiotem tej dziedziny teologicznej jest fakt zaistnienia Objawienia Bożego w historii oraz jego trwanie $w$ Kościele ${ }^{18}$. W tym znaczeniu wszystko, co związane z ludzkim życiem, wszelkimi jego wymiarami, w ramach teologii fundamentalnej, jest konfrontowane z Bożym Objawieniem. Dotyczy to także współczesnej kultury, warunkującej $\mathrm{w}$ dużej mierze życie człowieka, a w którą wpisują się naturalnie środki społecznego przekazu ${ }^{19}$.

\section{Tożsamość naukowa teologii środków społecznego przekazu}

Pytania dotyczące tożsamości naukowej skupiają się wokół zagadnień metodologicznych, a zatem m.in. definicji, źródeł oraz metod badawczych. Ponieważ prezentowany artykuł ma charakter problemowy, mający na celu wzbudzenie dyskusji na temat tych zagadnień, w tej części nie przedstawiono wszystkich odpowiedzi odnoszących się do metodologii teologii środków społecznego przekazu. Oprócz próby zdefiniowania oraz ukazania źródeł dla teologii mediów, zwrócono również uwagę na stan badań w Polsce w tym zakresie, co pozwoli ukazać rozwój refleksji teologicznej nad mediami i komunikacja, bądź też pewne ewentualne jego braki.

\section{Próba zdefiniowania}

Połączenie wyrażeń „teologia” i „media” lub „środki społecznego przekazu” wzbudzać może ożywioną dyskusję ${ }^{20}$. Można zauważyć dwie tendencje wśród teologów odnośnie do teologii mediów - teologii środków społecznego przekazu:

Pierwsza sugeruje, by nie traktować jej jako dyscypliny naukowej, czy kolejnej specjalności teologicznej, ale po prostu „refleksję teologiczną” nad środkami społecznego przekazu, mediami, przestrzenią medialną, nowymi mediami,

${ }^{17}$ Zob. Papieska Rada ds. Środków Społecznego Przekazu: Communio et progressio (CP) 11.

${ }^{18}$ M. R u s e c k i, J. M a s t e j: Metodologia teologii fundamentalnej. Demonstratio Christia$n a$, ,Studia Nauk Teologicznych PAN. T. 2: 2007 s. 96.

${ }^{19}$ Więcej na ten temat w: H. S e w e r y n i a k: Teologia na ,progu domu”. „Kultura-MediaTeologia". T. 1: 2010 s. 9-22.

${ }^{20}$ Pojęcia „media” oraz „środki społecznego przekazu” są przez autorkę używane zamiennie. Zasada ta dotyczy także „teologii mediów” oraz „teologii środków społecznego przekazu”. Poprzez „media” oraz „środki społecznego przekazu” rozumie się ,,środki wyrażania informacji”, np. naturalne i sztuczne języki' (...), ,środki rejestracji (zapisu) informacji, np. kartka i ołówek, magnetofon (...), ,środki transmisji (ściślej: dyfuzji) informacji, np. gazeta, kabel telewizyjny” (...), środki przetwarzania (w tym też wyszukiwania) informacji, np. komputer”. W. P is a r e k: Hasło „,Media”. W: Stownik terminologii medialnej. Red. W. P i s a r e k. Kraków 2006 s. 117. 
Internetem, komunikacją itd. To stanowisko sugeruje, by potraktować ją podobnie jak teologię cierpienia, teologię ciała ${ }^{21}$, teologię miłości, teologię rodziny, teologię polityczną ${ }^{22}$ itd. W tym znaczeniu można podać definicję teologii środków społecznego przekazu prof. dra hab. Karola Klauzy (KUL). Na jej określenie używa wyrażania „massmediologia teologiczna” i rozumie ją jako teologiczny namyst nad komunikowaniem masowym ${ }^{23}$. Tym kontekście teologia środków społecznego przekazu rozumiana byłaby jako ${ }^{24}$ :

- teologiczne spojrzenie na etykę mediów i etykę dziennikarską,

- teologiczne spojrzenie na edukację medialną,

- teologiczne spojrzenie na public relations,

- teologiczne spojrzenie na reklamę,

- teologiczne spojrzenie na komunikację społeczną,

- teologiczne spojrzenie na komunikację zapośredniczoną (Internet) itd.

Taka interpretacja teologii mediów czyni ją bardziej niezależną od innych teologicznych dziedzin. Rozumienie teologii środków społecznego przekazu jako teologiczną refleksję nad wykorzystaniem mediów w Kościele zamykałoby jej obszar badań wyłącznie w ramach teologii pastoralnej, co oczywiście jest ważne i potrzebne. Badania nad mediami w teologii mogą jednak sięgać dalej, według zaproponowanego wyżej schematu.

${ }^{21}$ Przyjrzyjmy się np. definicji teologii ciała w ujęciu J a n a P a w ła I I. W interpretacji T. $\mathrm{S} \mathrm{t} \mathrm{y} \mathrm{c} \mathrm{z} \mathrm{n} \mathrm{i} \mathrm{a} \mathrm{jest} \mathrm{ona} \mathrm{rozumiana} \mathrm{jako} \mathrm{„refleksja} \mathrm{filozoficzna} \mathrm{nad} \mathrm{ciałem} \mathrm{(...).} \mathrm{Jest} \mathrm{próbq} \mathrm{nakreślenia}$ możliwie petnej wizji czlowieka na podstawie Objawienia, jest więc przede wszystkim antropologia, antropologia teologicznq. Równocześnie antropologia ta posiada wymiar wybitnie etyczny: logos człowieka, który okazuje się logosem daru, przechodzi tu w etos daru. T. Styczeń: Ciało jak »znak obrazu Stwórcy«. W: Mężczyznq i niewiastq stworzyt ich. Chrystus odwotuje się do "poczqtku«. O Jana Pawła II teologii ciała. Red. T. S t y c z e ń. Lublin 2001 s. 88-89; zob. B. M i e r z w i ń s k i: Teologia ciała jako istotny aspekt malzeństwa w świetle katechez środowych Jana Pawła II. „Studia Pastoralne”. T. 5: 2009 s. 35-44.

${ }^{22}$ Rozumiana jako ,refleksja katolicka na tematy polityczne”. Zob. B. S e c 1 e r: Teologia polityczna -zarys problemu. W: Na obrzeżach polityki. Red. M. K o s m a n. Poznań 2010 s. 95.

${ }^{23}$ K. K 1 a u z a: Wnioski z „Aetatis novae”. W: Mediokracja w Polsce. Red. I. S k u b i ś. Częstochowa 2008 s. 72. Spojrzenie K. K l a u z y zasługuje na większą uwagę. Współczesne komunikowanie postrzega jako zagadnienie badawcze dla teologii moralnej, katechetyki, teologii pastoralnej, teologii duchowości, teologii biblijnej. Zob. K. K l a u z a: Polska teologia komunikowania społecznego. Wprowadzenie do dyskusji. W: Kościót w życiu publicznym. Teologia polska $i$ europejska wobec nowych wyzwań. Red. K. G ó ź d ź, K. K la u z a, Cz. R y c hli c k i i in. T. 1. Lublin 2004 s. 259-265.

${ }^{24}$ Takie rozumienie teologii środków społecznego przekazu pojawiło się również w wyniku obserwacji badań prowadzonych w Instytucie Edukacji Medialnej i Dziennikarstwa na Wydziale Teologicznym Uniwersytetu Kard. Stefana Wyszyńskiego w Warszawie, gdzie w obrębie pięciu katedr prowadzi się badania medioznawcze (z perspektywy humanistycznej lub socjologicznej) oraz teologiczne nad Internetem, public relations, reklamą, edukacją medialną, językiem mediów, komunikacją cyfrową oraz etyką mediów. 
Druga szkoła sugeruje, iż teologia środków społecznego przekazu to osobna dyscyplina naukowa. W tej grupie należy wymienić ks. prof. dr hab. Antoniego Lewka, założyciela Instytutu Edukacji Medialnej i Dziennikarstwa na Wydziale Teologicznym UKSW w Warszawie. Dwanaście lat po założeniu Instytutu (w 2003 r.) pisał tak: Czymś zupetnie nowym wydaje się być dyscyplina naukowa zwana teologiq środków społecznego przekazu lub teologia mass mediów. (...) Teologia mass mediów jest to nauka o technikach i procesie komunikowania $w$ aspekcie ich funkcji ewangelizacyjnej ${ }^{25}$. Autor powyższego stanowiska umiejscawiał teologię środków społecznego przekazu w ramach teologii praktycznej, obok takich dyscyplin szczególowych jak teologia katechezy czy teologia kaznodziejstwa lub w ramach teologii ewangelizacji ${ }^{26}$. Za przedmiot materialny przyją środki społecznego przekazu analizowane jako proces komunikowania oredzia zbawczego Chrystusa za pomoca mediów masowych ${ }^{27}$. Określenia „teologia komunikowania społecznego" oraz „teologia środków społecznego przekazu” uważał za równoznaczne, zamienne w myśl przekonania, iż forma przekazu jest także treścia przekazu, a przynajmniej nierozerwalnie z niq złaczona ${ }^{28}$. Spojrzenie to podziela również prof. dr hab. Katarzyna Pokorna-Ignatowicz, która dostrzega w „teologii mass mediów" młodq dyscypline nauk kościelnych" rozumianą jako teologiczne spojrzenie na proces komunikacji społecznej, co - jak autorka dalej wyjaśnia - oznacza, iż należy badać proces komunikacji i wnioskami wzbogacić teologie $^{29}$. W tym znaczeniu czymś naturalnym jest wykorzystywanie metod badawczych z nauk humanistycznych oraz społecznych przez badaczy teologii środków społecznego przekazu.

${ }^{25}$ A. L e w e k: Podstawy edukacji medialnej i dziennikarskiej. Warszawa 2003 s. 50-51. Potraktowanie teologii środków społecznego przekazu przez ks. prof. A. L e w k a wywołało i nadal wywołuje dyskusję wśród teologów. Jak zauważa K. K la u z a, dla ks. Lewka komentujacego przestanie massmediologiczne Vaticanum II oczywistym byto przekonanie, że środki komunikowania społecznego nie sq tylko technicznymi narzędziami shizacymi przekazywaniu informacji, ale stanowiq "podziwu godny dar Boga" (IM 1) ofiarowany człowiekowi dla przekazywania poprzez pokolenia zbawczego orędzia Chrystusa. (...) Dlatego naukowa refleksja nad naturq i soteriologiczna efektywnościq mediów w rozumieniu ks. Lewka stanowi podstawę dla uznania jej za odrębna dyscyplinę teologicznq - zarówno z warstwq traktatów systematycznych, a przede wszystkim pastoralnych. K. K l a u z a: Medialna eklezjogeneza w środowisku Uniwersytetu Kardynata Stefana Wyszyńskiego. Ksiqdz profesor Antoni Lewek (1940-2010) i jego spadkobiercy jego troski. „Kultura-Media-Teologia”. T. 6: 2011 s. 13.

${ }^{26}$ A. L e w e k: Podstawy edukacji..., dz. cyt., s. 51.

${ }^{27}$ Tamże.

${ }^{28}$ Tamże.

${ }^{29} \mathrm{~K}$. P o k o r n a - I g n a t o w i c z: Kościót w świecie mediów. Historia - dokumenty - dylematy. Kraków 2002 s. 140. 
W publikacjach K. Klauzy pojawią się także takie określenia, jak: teologia komunikacji, teologia komunikowania ${ }^{30}$, co jest szczególnie charakterystyczne dla środowiska teologów włoskich, którzy podejmują tę tematykę ściśle w obszarze teologii pastoralnej ${ }^{31}$. W związku z powyższym teologię środków społecznego przekazu należałoby wyraźnie odróżnić od teologii komunikowania (komunikacji). Wynika to głównie z naturalnego rozróżnienia pojęć - komunikacja i media. Ta pierwsza określa wymianę przekazów między uczestnikami komunikowania - nadawcą i odbiorcą ${ }^{32}$. By bardziej komunikację zrozumieć, warto wyróżnić w niej „komunikowanie”, czyli przekazywanie informacji, „komunikowanie się", oznaczające współudział, współuczestnictwo, prowadzące do zawiązania wspólnoty, oraz „komunikację” - przekaz ${ }^{33}$. Środki społecznego przekazu, określane także jako media, to pojęcie o bardzo szerokim zakresie pojęciowym. Oznaczać mogą one bowiem środki przetwarzania danych (komputer), środki rejestracji (magnetofon), wyrażania informacji (sztuczne języki) oraz środki transmisji (gazeta) ${ }^{34}$. A zatem komunikacja jest pojęciem o wiele szerszym od pojęcia media. Analogicznie to przedstawia się w przypadku teologii komunikacji oraz teologii środków społecznego przekazu, choć niekiedy stosuje się te określenia zamiennie. Definicję teologii komunikacji szczegółowo przeanalizował A. Jeż. Rozróżnił w niej trzy ujęcia ${ }^{35}$ :

- nauka o komunikacji rozumiana jest jako dyscyplina pomocnicza dla teologii, w myśl czego środki społecznego przekazu traktowane sa jedynie jako narzędzia, instrumenty dla teologii. Właściwym zaś podejściem - jak zaznacza autor - byłoby używanie środków społecznego przekazu lub doświadczenia komunikacji dla lepszego zrozumienia rzeczywistości wiary;

${ }^{30}$ Zob. K. K 1 a u z a: Polska teologia komunikowania spolecznego. Wprowadzenie do dyskusji. W: Kościół w życiu publicznym. Teologia polska i europejska wobec nowych wyzwań. Red. K. G ó ź d ź, K. K 1 a u z a, Cz. Rychlicki i in. T. 1. Lublin 2004 s. 259-265.

${ }^{31}$ Zob. G. Gi u 1 i od ori, G. L o ri zi o: Teologia e comunicazione. Milano, San Paolo 2001; D.E. V i g a n ò: La Chiesa nel tempo dei media. Roma 2008; Commissione Internazionale di Studio sui problemi della comunicazione nel mondo, Comunicazione e società oggi e domain. Torino 1982; Teologia e comunicazione. Edd. C. Guli o d or i, G. L or i zi o. San Paolo 2001; A. J o o s: Messaggio cristiano e comunicazione oggi. Verona 1988; A. P e 11 e g r i n i: Teologia come comunicazione. Firenze 2001; F. P o li, M. C a r d i n a li: La comunicazione in prospettiva teologica. Riflessioni sugli aspetti comunicativi della fede. Rivoli 1998; P.A SOUKUP: Communication, cultural form and theology. "The Way". Vol. 57: 1986 p. 77-89; A. S p a d a r o: Cyberteologia. Pensare il cristianesimo al tempo della rete. Milano 2012; D. V i g a n ò: La Chiesa nel tempo dei media. Roma 2008.

${ }^{32}$ R. B a r t o s z c z e: Komunikacja. W: Stownik terminologii medialnej. Red. W. P i s a r e k. Kraków 2006 s. 98.

${ }^{33}$ R. G o 1 ą b e k: Różnice między komunikowaniem bezpośrednim i masowym. W: Media audiowizualne i cyfrowe wobec wyzwań wspótczesnego spoleczeństwa. Red. A. A da m sk i, A. Gra l c z y k, K. K w a s i k, M. L a s k ow s k a. Warszawa 2012 s. 13.

${ }^{34}$ W. P i s a r e k: Media. W: Stownik..., dz. cyt., s. 117.

${ }^{35}$ A. J e ż: Jezus Chrystus w kontekście ludzkiej komunikacji. Tarnów 2002 s. 169-171. 
- teologia analizowana jest w świetle komunikacji, jej skuteczności komunikacyjnej; dotyczy teologii przepowiadania, ewangelizacji, w obrębie której stawia się pytania o przystosowanie się języka teologicznego do języka współczesnej komunikacji;

- teologia komunikacji interpretowana jest jako refleksja teologiczna nad komunikacją międzyludzką.

Prof. Norberto Gonzalez Gaitano (Pontifical University of the Holy Cross) zapytany przez autorkę o definicję oraz metodologiczne umiejscowienie teologii środków społecznego przekazu zaznaczył, iż lepiej mówić o teologii komunikacji, która funkcjonuje w obrębie teologii pastoralnej (przynależnej do teologii praktycznej), bądź też teologii dogmatycznej, w obszarze której analizowana jest komunia Trójcy Świętej według teologii komunikacji Trzech Boskich Osób. Od komunikacji Boga do komunikacji człowieka.

\section{Locus theologicus dla teologii środków społecznego przekazu}

Refleksja metodologiczna wokół teologii środków społecznego przekazu wzbudza także pytania o jej źródła. Źródła teologii, czyli locus theologicus, rozumiane są jako źródta teologii (...), z których teolog czerpie idee, konstruuje doktryne (...) poszukuje uzasadnień swoich tez ${ }^{36}$. Według M. Cano to przede wszystkim Loci proprii (miejsca własne teologii, podstawą których jest Boski autorytet - Pismo święte, Tradycja, Kościół katolicki, sobory powszechne, Kościół rzymski - Stolica Apostolska, Ojcowie Kościoła, teologowie i kanoniści) oraz Loci alieni (miejsca pomocnicze teologii oparte na ludzkim autorytecie rozum, filozofowie, historia) ${ }^{37}$.

W kontekście mediów pojawia się pytanie o to, czy mogą być one „miejscem teologicznym". Na przestrzeni lat schemat M. Cano ulegał zmianie. Dla potrzeb teologii środków społecznego przekazu autorka skupia się tylko nad źródłami pomocniczymi, gdyż podstawowe, takie jak Pismo święte i Tradycja są i będą zawsze aktualne. Wśród pomocniczych C. Napiórkowski wymienia m.in. sztukę, literaturę piękną ${ }^{38}$. Cz. S. Bartnik zaś oprócz podstawowych wymienia deklaratywne (akty hermeneutyki kościelnej, medialne (fakty Kościoła - rzeczywistość ontyczna Kościoła), pomocnicze (poznanie doczesne - filozoficzne, historyczne, przyrodnicze) oraz bezpośrednie (subiektywne - wewnętrzny świat człowieka $)^{39}$. W tych pomocniczych można by się doszukiwać odniesień do mediów. Tematykę mass mediów jako locus theologicus podjęła K. ParzychBlakiewicz. Według autorki mass media ujęte w kategoriach teologicznych jawia

\footnotetext{
${ }^{36}$ C. N a p i ó r k o w s k i: Teologia. Zagadnienia wstępne. Katowice 1986 s. 22.

37 Zob. J. S z y mik: Topika teologiczna wczoraj $i$ dziś. „Śląskie Studia HistorycznoTeologiczne". T. 13/14: 1990-1991 s. 159.

${ }^{38}$ C. N a pi ó r k ow s k i: dz. cyt., s. 23.

${ }^{39}$ Cz. S. B a rtnik: Kościót Jezusa Chrystusa. Wrocław 1982 s. 357-359; J. S z y mi k: dz. cyt., s. 163 .
} 
sie jako „miejsca teologiczne” - ze względu na ich naturę narzędziowa wzmacniajaca komunikację międzyludzkq. Należa do »miejsc historycznych "jako narzędzia wytworzone przez człowieka oraz zagospodarowane (wykorzystywane) do upowszechniania intencji, którq ma osoba nadawcy. "Zagadujqu, a więc właczaja się $w$ wymiar personalny »loci«, angażujac sferę aktywności osobowej nadawcy (ich dynamika jest na intencji aksjologicznej nadawcy) oraz odbiorcy (sq skierowane do sfery ludzkiego poznania oraz podlegaja weryfikacji krytycznego odbioru). (...) Mass media kwalifikuja się do miejsc teologicznych zależnych - historycznych, przedlużajacych i poszerzajacych obszar osobowy, upowszechniajacych Prawdę od osoby nadawcy oraz dynamizujacych aksjologicznie osobe odbiorcy ${ }^{40}$. W przypadku teologii środków społecznego przekazu źródła są tożsame $\mathrm{z}$ innymi specjalnościami teologicznymi.

\section{Stan badań w Polsce}

Badania dotyczące teologii środków społecznego przekazu podejmowane są na uniwersytetach jeszcze zasadniczo w niewielu placówkach w Polsce i na świecie. W przypadku Polski głównymi ośrodkami w tym temacie jest Uniwersytet Kardynała Stefana Wyszyńskiego w Warszawie (Instytut Edukacji Medialnej i Dziennikarstwa na Wydziale Teologicznym, założony w 2002 r. przez ś.p. ks. prof. Antoniego Lewka), Katolicki Uniwersytet Lubelski Jana Pawła II (Instytut Dziennikarstwa i Komunikacji Społecznej na Wydziale Nauk Społecznych) oraz Uniwersytet Papieski Jana Pawła II w Krakowie (Instytut Dziennikarstwa na Wydziale Nauk Społecznych).

Badania te mają także ogromny wkład w naukę Kościoła, i co więcej, wpływ na przenikanie treści biblijno-teologicznych z nauką o komunikowaniu i mediach. Tę właściwość współczesnej teologii środków społecznego przekazu widać wyraźnie na przykładzie analizy tematyki biblijnej w przekazie audiowizualnym, zwłaszcza w filmie, prowadzone m.in. przez pracowników naukowych Wydziału Teologicznego Uniwersytetu Opolskiego. Warto w tym miejscu wymienić organizowane tam konferencje naukowe (których owocem są cenne publikacje) na temat ewangelicznej interpretacji kina. Jak podaje M. Lis, to wtaśnie kino »ukrytej religijności«, przekraczajace ograniczenia wyznaniowe, często stawia widza wobec pytań, które prowadza w stronę transcendencji. Co więcej, historia kina dowodzi, że autorami ważnych filmów stawiajqcych pytania o sens życia, duchowość, Boga, nie zawsze byli ludźmi, dla których wiara była czymś oczywistym $^{41}$. Tego typu badania stanowią praktyczne przełożenie soborowych wytycznych o potrzebie obecności Ewangelii w środkach społecznego przekazu.

\footnotetext{
${ }^{40} \mathrm{~K}$. P a r z y c h - B l a k i e w i c z: Mass media jako, ,locus theologicus”. W: Media w transformacji. Red. A. G r a 1 c z y k, K. M a r c y ń s k i, M. P r z y b y s z. Warszawa 2013 (w druku).

${ }^{41}$ M. L i s: Figury Chrystusa w „Dekalogu” Krzysztofa Kieślowskiego. Opole 2007 s. 5. Inne publikacje w tym temacie to: Ukryta religijność kina. Red. M. L i s. Opole 2002.
} 
Są one konkretną, duchową pomocą dla odbiorcy, ponieważ łączą Ewangelię z codziennością, doszukując się motywów religijnych w filmach często i chętnie oglądanych. Takie podejście może zbliżyć człowieka do Kościoła, jego nauczania, a także zachęcić do zaangażowania się w podobne działanie ${ }^{42}$.

W Warszawie zaś w Instytucie Edukacji Medialnej i Dziennikarstwa na Wydziale Teologicznym Uniwersytetu Kard. Stefana Wyszyńskiego badania w zakresie teologii mediów podejmują głównie pracownicy Katedry Teologii Środków Społecznego Przekazu. Obejmują one m.in. następującą tematykę: audiowizualność w nauczaniu Kościoła ${ }^{43}$, wykorzystanie mediów w przekazie wiary ${ }^{44}$, ewangelizacja medialna ${ }^{45}$. Badania jednakże w zakresie teologii mediów podejmują również pracownicy pozostałych katedr: ks. dr hab. Andrzej Adamski ${ }^{46}$, prof. dr hab. Krystyna Czuba ${ }^{47}$, dr hab. Piotr Drzewiecki ${ }^{48}$, ks. dr Zenon Hanas ${ }^{49}$,

${ }^{42}$ Dobrym przykładem teologicznych badań nad audiowizualnością są także starania o audiowizualny przekład Biblii, co miałoby na celu „dotarcie do współczesnych odbiorców ze Słowem Bożym, aktualnym i znaczącym, wyrażonym w świeży i przekonujący sposób" (M. L i s: Audiowizualny przektad Biblii. Od translatio do transmediatio. Opole 2002 s. 8; zob. M. L i s: Biblia e ciemna. Quando un film è fedele al testo biblico? Estratto della tesi. Roma 2000). Na Uniwersytecie Kardynała Stefana Wyszyńskiego badania nad audiowizualnością kontekście teologii środków społecznego przekazu prowadzone są głównie przez G. Łę c i cki e go oraz P. D r ze wi e c k i e g o w kontekście zastosowania ich w edukacji medialnej oraz w katechezie.

${ }^{43}$ G. Ł ę c i c k i: Media audiowizualne w nauczaniu Jana Pawła II. Warszawa 2013; T e n ż e: Media wizualne a katecheza: zagrożenia, wyzwania, zastosowania. „Kultura-Media-Teologia”. T. 5: 2011 s. 73-84; T e n ż e: Teologia mediów audiowizualnych jako wyzwanie XXI wieku. „Kultura-Media-Teologia". T. 10: 2012 s. 8-17.

${ }^{44}$ K. M a r c y ń s k i: Środki masowego przekazu w stużbie apostolstwa. W: 100-lecie Stowarzyszenia Apostolstwa Katolickiego w Polsce. Red. A. D y r, R. F o r y c k i, M. K o w a l c z y k. Warszawa 2009 s. 359-363; T e n ż e: Głoszenie i rozpowszechnianie stowa Bożego. W: Apostolat Stowa Bożego. Red. M. Kowalczyk. Warszawa 2010 s. 336-347; T e n ż e: Liturgia Stowa w przekazie telewizyjnym. W: Msza św. w telewizji. Red. W. P r z y c z y n a. Kraków 2006 s. 65-84.

${ }^{45}$ P. M a c i a s z e k: Nauka Kościoła o roli mediów w społeczeństwie. „Zeszyty Prasoznawcze”. R. 211: 2012 s. 24-34. Troska o rozwój wiary chrześcijanina w świetle orędzi Benedykta XVI na Dzień Środków Społecznego Przekazu, w: Ks. Piotr Skarga - obrońca wiary i nauczyciel miłości Ojczyzny. Materiaty z sympozjum. Red. K. R a k, M. S z c z e r ba. Częstochowa 2012 s. $79-100$.

${ }^{46}$ Ksiadz w blogosferze. „Kultura-Media-Teologia”. T. 2: 2010 s. 99-111; Bt. ks. Ignacy Kłopotowski (1866-1931) - wychowawca świadomych, krytycznych i aktywnych odbiorców środków przekazu. „Biuletyn Edukacji Medialnej”. R. 1: 2010 s. 74-86; Media narzędziem humanizacji w świetle nr. 73. encykliki Benedykta XVI „Caritas in veritate”. W: Człowiek w medialnym labiryncie. Red. K. G u z e k, M. L a s k o w s k a. Warszawa 2011 s. 163-174; Od teologii środków spotecznego przekazu do dziennikarstwa i komunikacji spolecznej. Studia dziennikarskie na UKSW w Warszawie - historia i teraźniejszość. W: Dydaktyka dziennikarstwa. Opinie i postulaty. Red. S. G a w r o ń s k i. Kraków-Rzeszów-Zamość 2011 s. 345-352; Rodzina jako miejsce wychowania do korzystania z mediów w świetle nauczania Kościoła Katolickiego. W: Kaplan i rodzina w mediach. Red. A. A d a m s k i, K. K w a s i k, G. Ł ę c i c k i. Warszawa 2012 s. 129-136.

${ }^{47}$ Katolickie podstawy etyki dziennikarskiej. Torun 2007.

${ }^{48}$ Kto jest moim bliźnim $w$ wirtualnym świecie? Teologia społeczności sieciowych $w$ Orędziach Benedykta XVI na Światowe Dni Środków Społecznego Przekazu. „Łódzkie Studia Teolo- 
ks. dr Józef Kloch ${ }^{50}$, dr Małgorzata Laskowska ${ }^{51}$, dr Monika Przybysz ${ }^{52}$. Ogromny wkład w teologię środków społecznego przekazu ma również ks. prof. dr hab. Henryk Seweryniak ${ }^{53}$.

Jeśli zaś chodzi o badania w zakresie teologii środków społecznego przekazu prowadzone w Instytucie Dziennikarstwa i Komunikacji Społecznej na Wydziale Nauk Społecznych Katolickiego Uniwersytetu Lubelskiego Jana Pawła II, należy wymienić przede wszystkim wspomnianego prof. dra hab. Karola Klauzę ${ }^{54}$, a także ks. dra Marka Pytko ${ }^{55}$, ks. dra Jerzego Smolenia ${ }^{56}$.

giczne". R. 20: 2011 55-66; Christian discernment. Rozeznawanie duchowe jako metoda chrześcijańskiej interpretacji tekstów kultury medialnej. „Biuletyn Edukacji Medialnej”. R. 1: 2009 s. 4655; Nie lękajcie się nowych technologii! Edukacyjno-medialne przesłanie Listu Apostolskiego „,Szybki rozwój” Jana Pawła II. „, Łódzkie Studia Teologiczne”. R. 18: 2009 s. 61-67.

${ }^{49}$ Internet $w$ duszpasterstwie parafialnym. „Efektywne zarządzanie parafią”. T. 4: 2001 s. 122; Religie $w$ Internecie - Internet $w$ religiach. W: Media audiowizualne $i$ cyfrowe wobec wyzwań wspótczesnego spoleczeństwa. Red. A. A d a m s k i i in. Warszawa 2012 s. 239-255.

${ }^{50}$ Media w Kościele i Kościól w mediach. Edukacja medialna, dziennikarska $i$ w zakresie public relations oraz zastosowania Web 2.0 w Kościele w Polsce. Współred. M. P r z y b y s z. Katowice 2012 ss. 251; Internet i Kościót. Warszawa 2011 ss. 302; The Blogging Church. How to Use a Blog in the Church Mission. W: Religion and New Media in the Age of Convergence. Reading materials on media and religion for students. Red. V. K h ro ul. Moscow 2011 s. 63-76; EKościól? Miejsce informatyki i Internetu w przepowiadaniu. W: „Przekaż mojemu ludowi, co mówi Bóg”. Ewolucja czy kryzys przepowiadania?. Red. K. K l a u z a, M. W y r o s tk i e w i c. Lublin 2007 s. 113-122; Wyptynać na gtębię. Stosowanie technologii informatycznych i Internetu w Kościele w myśli Jana Pawła II. „Studia Elbląskie”. R. 7: 2006 s. 239-245.

${ }^{51}$ Teologiczne podstawy wychowania do galenosfery. „Paedagogia Christiana”. R. 2: 2009 s. 139-150; Sprawcza rola przekazu w „, Spe salvi”. W: Zbawienie w nadziei. Wokót encykliki Spe salvi Benedykta XVI. Red. K. P a r z y c h-B l a k i e w i c z. Olsztyn 2010 s. 143-158; Sprawcza rola przekazu $w$, Spe salvi”. W: Zbawienie w nadziei. Wokót encykliki Spe salvi Benedykta XVI. Red. K. P a r z y c h- B l a k i ew i c z. Olsztyn 2010 s. 143-158; Rodzina a nowe media. Analiza relacji na podstawie nauczania Kościoła. W: Ksiadz i rodzina..., dz. cyt., s. 138-150.

${ }^{52}$ Media w Kościele i Kościół w mediach..., dz. cyt.; Media i Kościót. Polityka informacyjna Kościoła. Współred. K. M a r c y ń s k i. Warszawa 2011 ss. 184; Public relations $w$ nowej ewangelizacji. W: Ewangelizacja odpowiedzia Kościoła w Polsce na wyzwania współczesności. Red. W. Przy goda, E. Robek. Sandomierz 2011 s. 401-432; Piarowiec eklezjalny. W: Oblicza wspótczesności. Red. E. Grzybowska, M. Przybysz, H. Seweryniak. Płock 2008 s. 157-162.

${ }^{53}$ Teologie na „progu domu”. „Kultura-Media-Teologia” R. 1: 2010 s. 10-23; Współaut.: Kultura, media, teologia. Metodyka pisania prac dyplomowych. Płock 2013.

${ }^{54}$ Prasa, radio, telewizja, film w nauczaniu Kościoła. Oprac. K. K 1 a u z a. Warszawa 1992 ss. 84; Kościót o środkach komunikowania myśli. Oprac. J. G ó r a l, K. K l a u z a . Częstochowa 1997 ss. 388; Kościót w życiu publicznym. Teologia polska i europejska wobec nowych wyzwań. T. 1. Wykłady i wprowadzenia do dyskusji grupowych. Red. K. Gó ź d ź i inni. Lublin 2004 ss. 474 [współredaktor]; Kościół w życiu publicznym. Teologia polska i europejska wobec nowych wyzwań. T. 2. Materiały spotkań sekcyjnych. Red. K. Gó ź d ź i in. Lublin 2004 ss. 576 [współredaktor]; Kościót w życiu publicznym. Teologia polska i europejska wobec nowych wyzwań. T. 3. Red. K. Gó ź d ź i in. Lublin 2005 ss. 791; ,,Przekaz mojemu Ludowi co mówi Bóg”. Ewolucja czy kryzys przepowiadania? Red. K. K l a u z a, M. W y r o s t k i e w i c z. Lublin 2007 ss. 324; Prawda zdarzeń, komunikatu i osoby $w$ kontekście komunikacji społecznej. „Kultura-Media-Teologia”. R. 
W Instytucie Dziennikarstwa na Wydziale Nauk Społecznych Uniwersytetu Papieskiego Jana Pawła II w Krakowie na uwagę zasługuje fakt, iż w ramach Instytutu działają dwie katedry nawiązujące do refleksji teologicznej nad mediami: Katedra Duchowości Mediów i Relacji Społecznych oraz Katedra Teologii Mediów. Nawiązując do badań, wymienić należy chociażby następujące nazwiska: ks. prof. dr hab. Andrzej Baczyński ${ }^{57}$, ks. prof. dr hab. Wojciech Misztal ${ }^{58}$. Do grona wzbogacających myśl teologii środków społecznego przekazu można także zaliczyć ks. dra. hab. Michała Drożdża, prof. UPJPII (etyk, filozof mediów) ${ }^{59}$. Wśród naukowego środowiska krakowskiego wymienić także warto prof. nadz. dr hab. Katarzynę Pokorną-Ignatowicz z Krakowskiej Akademii im. Andrzeja Frycza Modrzewskiego, zajmującą się wprawdzie bardziej medioznawstwem, komunikowaniem masowym, komunikowaniem politycznym, jednakże wśród jej bogatego dorobku można wymienić kilka publikacji, nawiązujących do relacji Kościół - media. Na uwagę zasługuje przede wszystkim publikacja pt.

7:2011 s. 16-24; Medialna eklezjogeneza w środowisku Uniwersytetu Kardynała Stefana Wyszyńskiego. „Kultura-Media-Teologia”. R. 6: 2011 s. 8-17; Eklezjogenetyczna funkcja środków spotecznego przekazu. W: Kościól a środki społecznego przekazu. Red. J. Chrapek. Warszawa $1990 \mathrm{s.}$ 160-171; Kultura a środki społecznego przekazu. Analiza społeczno-pastoralna. W: Kościót a środki społecznego przekazu. Red. J. Chrape k. Warszawa 1990 s. 88-102 [współautor: A. R u s z k ow s k i]; Duszpasterskie implikacje „Aetatis novae”. Bilans pięciolecia. W: Prasa katolicka między ekonomia a duszpasterstwem. Red. K. K 1 a u z a. Częstochowa 1997 s. 45-61; „Katechizm Kościoła Katolickiego" $i$ inne dokumenty nauczania Magisterium Kościoła o mediach masowych. W: Religia a mass media. Znaczenie środków spolecznego przekazu w kulturze religijnej Polski. Red. W. Z d a n i e w i c z. Ząbki 1997 s. 10-16; Odpowiedzialność za słowo i obraz wedtug Magisterium Kościoła. W: Katolicyzm społeczny a Polska współczesna. III Tydzień społeczny, 1318 maja 1996 r. Przemówienia i materiaty. Warszawa 1997 s. 173-187; Polska teologia komunikowania społecznego. W: Kościól w życiu publicznym. Teologia polska i europejska wobec nowych wyzwań. T. 1 Wyktady i wprowadzenia do dyskusji grupowych. Red. K. G ó ź d ź i in. Lublin 2004 s. 259-265; E-teologia? W: Wyzwania współczesnej edukacji-e-nauczanie. Red. R. P o d p o r a, Lublin 2006 s. 7-10.

${ }^{55}$ Informacja $w$ życiu Kościoła, a media. W: Jaka informacja? Red. L. D y c z e w s k i. Lublin 2009 s. 209-219; Elementy tożsamościowe mediów katolickich w nauczaniu Jana Pawła II. W: Tożsamość a komunikacja, Red. L. D y c z e w s k i, Lublin 2009 s. 233-244.

${ }^{56}$ Media $w$ duszpasterstwie. Z nauczania Kościoła. „Biuletyn Edukacji Medialnej”. R. 1:2006 s. 62--70; Media w duszpasterstwie. Niepokój Kościoła. „Biuletyn Edukacji Medialnej”. R. 1: 2006 s. 11-16; Internet jako medium komunikacyjne w Kościele, na przykładzie Diecezji Tarnowskiej. „Biuletyn Edukacji Medialnej”. R. 1: 2008 s. 116-128.

${ }^{57}$ Przekaz i formacja wiary przez media. W: Teologia pastoralna nauka $w$ stużbie nowej ewangelizacji. Red. Cz. Krakowiak, W. Przygoda, A. Kiciński. Lublin 2010 s. 105-121.

${ }^{58}$ Odpowiedzialność: niezbędna pomoc czy uciqżliwa przeszkoda? Przyczynek do relacji między chrześcijaństwem i mediami. W: Odpowiedzialność w mediach - od przypadku do celu. Red. A. B a c z y ń s k i, M. D r o ż d ż. Tarnów 2012 s. 49-64; Media jako sprzymierzeniec duchowości. W: Wartości w mediach $-z$ dolin na szczyty. Red. A. Baczyński, M. Drożdż. Tarnów 2012 s. 277-301; Duchowość mediów i relacji społecznych. „Studia Socialia Cracoviensia”. R. 5: 2012 s. 9-22.

${ }^{59}$ Jan Pawet II - oblicza dobrego czlowieka z perspektywy mediów. „Biuletyn Edukacji Medialnej”. R. 1: 2009 s. 5-18; Troska o przekaz wiary w mediach. „Polonia Sacra”. R. 12: 2008 s. $53-78$. 
Kościót w świecie mediów. Historia - dokumenty - dylematy (Wydawnictwo UJ, Kraków 2002), w której nie brakuje pionierskich myśli w zakresie teologii mediów, zasługujących na kontynuację w badaniach ${ }^{60}$.

Oprócz badań naukowych prowadzone są także studia, np. doktoranckie ze specjalności teologii środków społecznego przekazu na Uniwersytecie Kard. Stefana Wyszyńskiego w Warszawie. Założyciel Instytutu Edukacji Medialnej i Dziennikarstwa na Wydziale Teologicznym UKSW w Warszawie, ks. prof. Antoni Lewek podał, iż podstawowym ich założeniem jest kształcenie dziennikarzy prasowych, radiowych, telewizyjnych, pracowników agencji informacyjnych, marketingu, public relations, rzeczników prasowych, nauczycieli edukacji medialnej ${ }^{61}$.

Wyżej zasygnalizowany stan polskich badań w zakresie teologii mediów i komunikacji można ocenić pozytywnie, ale zaznaczając, iż można tą tematyką zająć się jeszcze bardziej. Zdaniem prof. dra hab. K. Klauzy program polskiej teologii komunikacji zyskuje już coraz bogatsza literaturę, przeradza się w forme wykładów akademickich $i$ zaczyna stopniowo przechodzić $w$ sfere popularyzacji $^{62}$. Zapewne do większej popularyzacji przyczyniłoby się organizowanie konferencji na temat tożsamości naukowej teologii mediów, z udziałem różnych ośrodków akademickich, zwłaszcza wydziałów teologicznych.

\section{Obszary dzialań proponowane przez Kościól}

Na podstawie posoborowego nauczania Kościoła można wyłonić trzy obszary działań w zakresie teologii środków społecznego przekazu. Pierwszy obejmują badania naukowe (pilne zagadnienia, które należałoby podjać $\mathrm{w}$ ramach pracy badawczej na uniwersytetach na wydziałach teologicznych). Drugi obszar obejmuje działania praktyczne, wynikające z naukowych badań, a mające przełożenie na konkretne przestrzenie życia prywatnego lub społecznego (np. działania duszpasterskie w obrębie parafii). Trzeci obszar działań proponowanych przez Kościół to edukacja - kształcenie w zakresie teologii środków społecznego przekazu oraz dziennikarstwa.

\section{Kierunki badań naukowych}

Kościół w dokumentach poświęconych tematyce medialnej wielokrotnie daje sygnały, by naukowo - na kanwie teologii - zająć się problematyką mediów ${ }^{63}$.

\footnotetext{
${ }^{60}$ Nie sposób wymienić wszystkich polskich badaczy zajmujących się powiązaniami teologii i mediów. Niewątpliwie na osobne opracowanie zasługuje wkład śp. bpa dra Jana C hrapka w teologię mediów i teologię komunikacji.

${ }^{61}$ Por. A. L e w e k: Podstawy edukacji..., dz. cyt., s. 30.

${ }^{62}$ K. K 1 a u z a: Polska teologia komunikowania społecznego..., dz. cyt., s. 222.

${ }^{63}$ Zob. Papieska Rada ds. Środków Społecznego Przekazu: Aetatis novae (AN) 17.
} 
W „Aetatis novae” używa określenia „teologia komunikacji”, ${ }^{4}$. Jest to jedyne w nauczaniu Kościoła takie określenie, które stanowi sprecyzowanie specjalności teologicznej, poświęconej komunikowaniu się za pomocą mediów. Poniżej przedstawiono kierunki badań naukowych $\mathrm{w}$ zakresie mediów, proponowanych przez Kościół w nauczaniu posoborowym.

\section{"Rozwój antropologii i teologii komunikacjiı ${ }^{65}$}

Ta myśl zawarta w „Aetatis novae” wyrażałaby przede wszystkim potrzebę skupienia się na procesie komunikacji, zwłaszcza na komunikacji między Bogiem a człowiekiem. Przez jej pryzmat należałoby pytać o znaczenie współczesnych środków komunikowania: Na ile są one pomocne w poznawaniu Boga, w umacnianiu relacji z Nim? Co w nowoczesnych formach komunikacji jest mocną stroną, a co słabą? Co sprawia (jakie treści, jakie formy przekazu), że media przybliżają nas do Boga (ułatwiają nam rozmowę z Nim)? A co w środkach społecznego przekazu jest przeszkodą ku temu? Pytania te sprowadzają się do pytań o narzędzie (możliwości technologiczne), jakim są media, o treści przekazywane przez nie, a także o media jako instytucje. W przypadku tego ostatniego pojawia się pytanie o to, czy stwarzają one warunki dla przekazu wartości.

Antropologia komunikacji - zasygnalizowana we wspomnianym dokumencie - zajmowałaby się komunikującymi, a zatem odnosi się bardzo ściśle do człowieka. A ponieważ komunikacja jest sposobem bycia, zadaniem badaczy antropologii komunikacji jest m.in. zwrócenie uwagi na ludzkie zdolności do komunikowania się ${ }^{66}$.

W „Aetatis novae” zwrócono również uwagę na potrzebę prowadzenia badań w zakresie teologii komunikacji, o czym więcej wspomniano przy okazji próby zdefiniowania jej. Warto jednakże w tym miejscu przywołać słowa $\mathrm{T}$. Chromika, który zaznaczył, iż jest rzeczq wprost szokujacq $i$ nie do wiary, iż Kościól, chcqc wyrazić teologiczna naturę i istotę środków społecznego przeka$z u$, siega aż do Chrystusa, jako do najwspanialszego wzoru komunikowania, jaki jest dostęny ludziom na ziemi ${ }^{67}$. W Jego osobie ukazuje normy i formy dla komunikacji. Komunikacja zaś wpisuje się w przekaz wiary. Są to przestrzenie, które naturalnie ze sobą współgrają bądź też nie. Analizując zatem Chrystusa komunikującego, badamy także Jego sposób przekazu wiary, a zatem gesty, język przekazu itp. W zgłębianiu stylu komunikowania się Chrystusa odnaleźć

\footnotetext{
${ }^{64}$ AN 8.

${ }^{65}$ Tamże.

${ }^{66}$ Zob. P. H e n ri ci: Ku antropologicznej filozofii komunikacji. Tłum. K. B is k u p s k i. W: Kościół a środki społecznego przekazu. Red. J. C h r a p e k. Warszawa 1990 s. 33.

${ }^{67}$ T. C h ro m i k: Środki społecznego przekazu na tle duszpasterskich zadań i potrzeb Kościoła. W: Kościót a kultura masowa. Red. F. A d a m s k i. Kraków 1984 s. 82.
} 
można ogromną furtkę do badań dla teologów zajmujących się przekazem wiary, komunikacją bądź też narzędziami, służącymi do porozumiewania się.

\section{Wirtualna rzeczywistość a realna obecność Chrystusa}

Do tematów badawczych w dokumentach Kościoła zalicza się także przestrzeń wirtualną, Internet. W dokumencie „Kościół a Internet” zauważono, iż w wyniku „wszechobecnego" Internetu dochodzi do wielu nadużyć, także natury religijnej i duchowej. Szczególnie niebezpieczna jest próba przenoszenia (fizycznego i duchowego) sakramentów do świata cyfrowego, szukanie w Internecie narzędzi ich sprawowania i umiejscowienia. Problem ten zaistniał dużo wcześniej, gdy pojawiło się radio i telewizja. Stawiano wówczas pytanie o dopuszczalność transmisji Mszy Świętej za ich pośrednictwem ${ }^{68}$. Tak jak zaznaczył A. Draguła, istotnym niebezpieczeństwem jest także to, iż wielu oglqdajacych nie dostrzega różnicy pomiędzy dziejqca się rzeczywistościq a jej transmitowanym obrazem, co w konsekwencji może prowadzić do przekonania, że udział w Eucharystii jest tak samo możliwy w przypadku transmisji, jak i poprzez fizycznq obecność ${ }^{69}$. O podobną refleksję apeluje Kościół także w odniesieniu do Internetu. Wirtualna rzeczywistość cyberprzestrzeni niesie z sobq pewne niepokojace implikacje dla religii, jak $i$ dla innych dziedzin życia. Rzeczywistość wirtualna nie jest zamiennikiem Realnej Obecności Chrystusa w Eucharystii, sakramentalnej rzeczywistości innych sakramentów $i$ wspóludziatu $w$ kulcie sprawowanym $w$ żywej wspólnocie. W Internecie nie ma sakramentów; a nawet doświadczenia religijne, możliwe w nim dzięki tasce Boga nie sq wystarczajace w oderwaniu od wspótdziałania z innymi wiernymi w świecie rzeczywistym. To kolejny aspekt Internetu, który wymaga studium i refleksji $i^{70}$.

\section{Internet a ksztaltowanie postaw religijnych}

Papieska Rada ds. Środków Społecznego Przekazu w dokumencie „Kościół a Internet" zauważa kolejny pilny problem do naukowego zgłębiania. W tym zakresie wielce przyczynić mogą się teolodzy i etycy. Kościół bowiem dostrzega niebezpieczeństwo kształtowanie postaw religijnych wzorowanych na zachowaniach konsumenckich. To konsumenckie podejście do zagadnień wiary - jak

\footnotetext{
${ }^{68} \mathrm{~W}$ latach trzydziestych dwudziestego wieku zagadnieniem tym interesował się także młody ks. Stefan W y s zy ński. Jeśli chodzi o transmisję Eucharystii za pomocą radia, obserwował doświadczenie Węgrów, zgłębiając jednocześnie ówczesne nauczanie Kościoła. Dostrzegał w ludziach ogromny głód wiary, który mogą po części zaspokajać dzięki radiu, stąd też określił je jako ,potęgę przez Opatrzność wskazaną”. Przy tym jednakże zaznaczał, iż transmisja Mszy przez radio nie zastąpi w pełni realnej obecności. Więcej na ten temat w rozdziale pt. „Radio narzędziem duszpasterstwa" w książce M. L a s k o w s k i e j pt. Ksiq̨dz Stefan Wyszyński jako dziennikarz i redaktor (1924-1946). Toruń 2011 s. 262-269.

${ }^{69}$ A. D r a g u 1 a: Eucharystia zmediatyzowana. Teologiczno-pastoralna interpretacja transmisji Mszy Świętej w radiu i telewizji. Zielona Góra 2009 s. 332.

${ }^{70}$ Papieska Rada ds. Środków Społecznego Przekazu: Kościół a Internet (KI) 9.
} 
podano w dokumencie - objawia się przede wszystkim w wybieraniu elementów religijnych, pasujacych do (...) osobistych gustów ${ }^{71}$. Jest to swego rodzaju selektywność w uznawaniu nauczania Kościoła. To zagadnienie ważne o tyle, że nawiązuje do wpływu kultury masowej, popularnej, niosące wiele zagrożeń.

\section{„Info-etyka”}

Kościół w mediach dostrzega pozytywne oddziaływanie na życie człowieka oraz wpływ na rozwój przestrzeni życia publicznego, jednakże zwraca także uwagę na nadużycia natury etycznej i moralnej, które dokonują się za przyczyną środków społecznego przekazu. Stąd też wielokrotnie zwraca uwagę na potrzebę większej społecznej etycznej wrażliwości na naruszenia norm, obowiązujących zwłaszcza nadawców (dziennikarzy, producentów i wszystkich pracujących w mediach). Benedykt XVI w jednym z orędzi na Światowy Dzień Środków Społecznego Przekazu zaznaczył, iż dziś jest potrzebna w tej dziedzinie swoista »info-etyka«, przez analogię do bioetyki, istniejacej na polu medycyny i badań naukowych dotyczacych życia ${ }^{72}$. Badania $\mathrm{w}$ tym zakresie wymagają nieustannej konfrontacji z tym, co nowe. Warto zatem poddać szczegółowej analizie działania użytkowników portali społecznościowych, tak bardzo popularnego narzędzia komunikacji, a także formy i sposoby „tworzenia”, pozyskiwania oraz przekazywania informacji w dobie dziennikarstwa obywatelskiego, internetowego. Pilnym zadaniem - w kontekście programów studiów różnych kierunków - jest także reorganizacja nauczania etyki na uczelniach wyższych. Oprócz teorii etyki trzeba podjąć żywą dyskusję ze studentami na tematy współczesne, pytając o to, jak w danej, konkretnej sytuacji należałoby się zachować, co jest właściwe, dobre itd. Warto także pomyśleć nad tym, w jaki sposób młodych zainteresować zagadnieniami etycznymi. Prof. Claude-Jean Bertrand (Université Paris II) za punkt wyjścia nauczania etyki dziennikarskiej, etyki mediów przyjął założenie, iż etyka jest wyrazem zawodowego profesjonalizmu. Uczył studentów, że przestrzeganie zasad etycznych „opłaca się” (,,being ethical is good business”"73). Może właśnie w ten sposób więcej młodych ludzi bardziej zainteresuje się etyką (jako teorią, nauka), ale przede wszystkim podstawą działania, formacji zawodowej.

W teologii mediów również nie może zabraknać nawiązań do etyki mediów, etyki dziennikarskiej. Teologia może stanowić dodatkowe źródło dla interpretacji postępowań ludzi mediów oraz funkcjonowania współczesnych mediów. Innym pilnym zdaniem dla badaczy (filozofów, teologów, medioznawców) są metodo-

\footnotetext{
${ }^{71}$ Tamże.

${ }^{72}$ B e n e dy k t X V I: Środki społecznego przekazu na rozdrożu między gwiazdorstwem a stużba. Szukać prawdy, by się niq dzielić. Orędzie na 42. Światowy Dzień Środków Spolecznego Przekazu (2008). „L'Osservatore Romano”. Wydanie polskie. R. 29: 2008 nr 3 s. 8 pkt 3.

${ }^{73}$ I. P a p a d o p o u 1 o s: Claude-Jean Bertrand Obituary. „Media Ethics”. Vol. 19: 2007. http://www.mediaethicsmagazine.com/index.php/browse-back-issues/137-fall-2007/3227314claude-jean-bertrand-obituary (dostęp: 13.04.2013).
} 
logiczne podstawy zajmowania się etyką mediów w ramach teologii mediów, teologii komunikacji. Pojawią się bowiem pytania: Na ile można zajmować się etyką w ramach teologicznej dyscypliny? Na ile, w jaki sposób można zajmować się etyką mediów w ramach teologii mediów? Jakie tematy byłyby na niej poruszane? ${ }^{74}$

\section{Oddzialywanie mediów}

To kierunek badań naukowych zawsze aktualny, sygnalizowany niemalże w każdym dokumencie Kościoła o mediach, kierowany do psychologów, mediozawców, pedagogów, ale także teologów. Konkretnym przedmiotem tych badań byłoby przede wszystkim oddziaływanie środków społecznego przekazu na dzieci i młodzież. W związku z tym zagadnieniem Jan Paweł II podaje, iż należałoby zweryfikować rzeczywiste skutki, jaki wywiera ono [oddziaływanie mediów] na odbiorcach, w których jeszcze nie dojrzała dostatecznie krytyczna świadomośc ${ }^{75}$. Opracowań na ten temat jest coraz więcej, niemniej jednak warto nieustannie badania te aktualizować, konfrontując je ze współczesnymi wyzwaniami. Oddziaływanie mediów na dzieci i młodzież - jako temat badawczy - wpisuje się także w zadania teologii mediów. Przed przystąpieniem do nich warto uporządkować kwestie metodologiczne: Na ile można, jeśli tak, to w jaki sposób zajmować się pedagogiką mediów w ramach teologii? Jakie tematy byłyby poruszane w ramach pedagogiki mediów na wydziale teologicznym?

Wyższej wymienione kierunki badań naukowych, które warto podjąć w ramach teologii mediów, to tylko kilka spośród wymienionych w nauczaniu Kościoła o mediach. Zadaniem teologa, podejmującego zagadnienia mediów i komunikacji, jest uważna lektura Magisterium Kościoła pod kątem badań naukowych. Dotyczy to szczególnie nowych wypowiedzi, np. orędzi na Światowy Dzień Środków Społecznego Przekazu.

\section{Kierunki dzialań praktycznych}

W nauczaniu Kościoła o mediach znacznie więcej jest wskazań praktycznych. Wiele z nich, wydanych po „Inter mirifica” ma charakter instrukcji, co już sygnalizuje przełożenie teorii na praktykę. Poniżej jedynie dwa $\mathrm{z}$ nich zostaną wymienione.

\footnotetext{
${ }^{74} \mathrm{Na}$ UKSW w Warszawie istnieje Instytut Edukacji Medialnej i Dziennikarstwa, w ramach którego można podjąć studia doktoranckie z teologii środków społecznego przekazu. W ramach także tego Instytutu działa Katedra Teorii, Prawa i Aksjologii Mediów, podejmująca badania głównie w zakresie etyki mediów, etyki dziennikarskiej.

${ }^{75} \mathrm{~J}$ a n P a w e 1 I I: Komunikacja społeczna $w$ stużbie chrześcijańskiej promocji młodzieży (1985). W: Orędzia ..., dz. cyt., s. 133 pkt 4.
} 


\section{Wykorzystać Internet w duszpasterstwie i w katechezie}

To jedna z propozycji kierunków działań praktycznych, na jaką wskazuje Kościół, a która w dobie współczesnych mediów jest szczególnie ważną kwestią $^{76}$. Szczegółowe wytyczne na ten temat można odnaleźć w dokumencie „Kościół a Internet”. Obszary działalności duszpasterskiej (parafie, wspólnoty, grupy parafialne) stanowią właściwą przestrzeń, w której można człowieka przeprowadzić z cyberprzestrzeni do prawdziwej wspólnoty ${ }^{77}$. Jest to miejsce, w którym następuje realne przejście od komunikacji do communio. Inną pilną kwestią na tym polu jest zastosowanie Internetu w katechezie oraz nauczaniu, czyli ogólnie rzecz ujmując $\mathrm{w}$ przekazie wiary ${ }^{78}$. Takie działanie może być następstwem badań naukowych, prowadzonych na wydziałach teologicznych przy użyciu szczególnie narzędzi socjologicznych i pedagogicznych. Badania empiryczne pozwoliłby praktykom odnaleźć odpowiedzi na pytania o ,skuteczność działań katechetycznych"79.

\section{Popierać dobre media}

Ważne jest, by zarówno w dyskursie naukowym, jak i w działaniu praktycznym nie dominowała postawa krytykanctwa wobec mediów. Środki społecznego przekazu mogą być również narzędziem dobra, na co nadal podaje się zbyt mało przykładów, zwłaszcza w przekazie skierowanym do młodzieży. W soborowym dokumencie „Inter mirifica” zaznaczono wyraźnie, iż wszelkimi skutecznymi środkami należy popierać i otaczać opieka produkcję i rozpowszechnianie filmów, stużacych godziwej rozrywce, kulturze i sztuce, szczególnie zaś przeznaczonych dla młodzieży. Cel ten osiagnie się, wspierajac i koordynujac wysitki oraz inicjatywy uczciwych producentów i dystrybutorów, polecajac filmy godne uznania wedlug powszechnej opinii krytyków $i$ wyróżnione nagrodami oraz popierajac $i$ łaczac $w$ zwiqzki kina prowadzone przez katolickich $i$ uczciwych przedsiębiorców $w^{80}$. Słowa te mają na uwadze konkretne działanie - postawę czynnego, świadomego odbiorcy przekazy medialnego. Jest to o wiele trudniejsze zadanie niż pasywne przyglądanie się coraz liczniejszym nadużyciom etycznym w mediach. Kościół poprzez coraz odważniejsze korzystanie z najnowszej technologii, współczesnych form komunikacji (np. serwisów społecznościowych)

${ }^{76} \mathrm{KI}$ 8; zob. J a n P a w e 1 I I: List apostolski Novo Millennio Ineunte 39.

${ }^{77} \mathrm{KI} 9$.

${ }^{78}$ Zob. KI 9; K. M a r c y ń s k i: Środki masowego przekazu w stużbie apostolstwa. W: 100lecie Stowarzyszenia Apostolstwa Katolickiego..., dz. cyt., s. 359-363; J. K 1 o c h: Kościół blogujacy..., dz. cyt., s. 215-226; K. K l a u z a: Media w nowoczesnej parafii. Sugestie pastoralne stare i nowe. Czestochowa 2003.

${ }^{79}$ P. T o m a s i k: Metodologia katechetyki podstawowe zagadnienia. „Studia Nauk Teologicznych PAN". T. 2: 2007 s. 285.

${ }^{80}$ IM 14. 
ukazuje, iż mogą one być narzędziem ludzkiego rozwoju duchowego, religijnego oraz moralnego.

\section{Edukacja w zakresie teologii środków społecznego przekazu oraz dziennikarstwa}

Oprócz konieczności podjęcia wyżej wymienionych kierunków badań w zakresie teologii mediów, a także działań praktycznych (szczególnie duszpasterskich), trzeba również zwrócić uwagę - jak to określono w dokumencie „Kościół i Internet" - na bardziej zaawansowane ksztatcenie $w$ dziedzinie technologii środków społecznego przekazu ${ }^{81}$. Obok jednakże pogłębiania wiedzy i umiejętności technologicznej Kościół zachęca, by zwiększać kompetencje także w zakresie zarządzania oraz etyki. Powyższy apel ten można by rozumieć w dwojaki sposób - jako kształcenie uniwersyteckie oraz samodzielne doszkalanie się w tych zagadnieniach. W przypadku nauczania akademickiego coraz częściej i chętniej sięga się do coraz nowszej technologii, jednakże warto przyjrzeć się bliżej takich przedmiotom, jak etyka, stawiając pytanie o odniesienia do współczesnych mediów, czyli interaktywnych, cyfrowych, określanych często nowymi mediami $^{82}$. Na ile są one brane pod uwagę podczas zajęć? Na ile dylematy etyczne powstałe w wyniki ekspansji nowych mediów, mediów cyfrowych, komunikacji sieciowej są poruszane na takich przedmiotach, jak etyka dziennikarska czy etyka mediów? Zasady etyczne są oczywiście niezmienne, stałe, ale warto je weryfikować ze współczesnymi realiami i odnosić do aktualnego kontekstu uprawiania dziennikarstwa ${ }^{83}$. Sobór Watykański II zachęcał, by nieustannie analizować zasady porzadku moralnego ${ }^{84}$ oraz tę wiedzę rozpowszechniać. Znajomość ta pozwoli przede wszystkim na właściwe korzystanie ze środków społecznego przekazu. Jak słusznie zaznaczono w dokumencie „Etyka w reklamie”, porzqdek moralny, na który powotuje się sobór, to prawo naturalne, które obowiazuje wszystkich, ponieważ wpisane jest $w$ ich serca (por. Rz 2,15) i zawiera nakazy stużce realizacji człowieka ${ }^{85}$.

${ }^{81}$ KI 11; Teoretyczne i praktyczne przygotowanie do pracy w mediach winno się odbywać w seminariach, stowarzyszeniach, w różnych ruchach kościelnych, zwłaszcza młodzieżowych. Zob. J a n P a w e 1 I I: Komunikacja społeczna w stużbie chrześcijańskiej promocji młodzieży. Orędzie 19. Światowy Dzień Środków Społecznego Przekazu (1985). W: Orędzia..., dz. cyt., s. 135 pkt 6.

${ }^{82}$ M. S z p u n a r: Czym sq nowe media - próba konceptualizacji. „Studia Medioznawcze”. T. 4: 2008 s. 31-40.

${ }^{83}$ Zob. Z. S a r eło: Media w stużbie osoby. Etyka społecznego komunikowania. Toruń 2002 s. 8; M. L a s k o w s k a: Nowe media - nowa etyka? W: Nowe media, ale nowe czy stare proble$m y$ ? Red. J. H a j d a s z. Poznań 2011 s. 97-116. Autorka przeprowadziła badania dotyczące etyki dziennikarskiej jako przedmiotu akademickiego wśród studentów polskich, by ukazać jego słabości oraz wyzwania, jakie wynikają $\mathrm{z}$ nowego i współczesnego rynku pracy (oczekiwań przyszłych dziennikarzy).

${ }_{84}^{84}$ IM 4.

${ }^{85}$ Papieska Rada ds. Środków Społecznego Przekazu: Etyka w reklamie 14. 
Kościół również zachęca (i to w wielu dokumentach) do edukowania w zakresie mediów seminaria duchowne oraz zgromadzenia zakonne w myśl słów z "Communio et progressio": niech kandydaci do kaptaństwa, zakonnicy i zakonnice ksztatcacy się $w$ seminariach $i$ domach formacji nie pozostaja $z$ dala od zycia $i$ nie przystepuja do pracy duszpasterskiej bez odpowiedniego przygotowania. Niech należycie poznajq wpływ środków przekazu na społeczeństwo, a także zapoznaja się z technikq ich wykorzystania; wiedze te należy traktować jako integralnq czesść ich formacji ${ }^{86}$. Edukacja ta powinna obejmować kształcenie w zakresie trzech poziomów wiedzy i kompetencji: formacja odbiorców, formacja duszpasterska oraz przygotowanie specjalistyczne (dla tych, którzy będą pracować i posługiwać w mediach) ${ }^{87}$.

Od momentu wydania „Inter mirifica” oraz dokumentu uzupełniającego instrukcji duszpasterskiej „Communio et progressio” (1971) - zaczęto łączyć teologię ze środkami społecznego przekazu na kanwie badań naukowych. Efektem zainteresowania Kościoła mediami jest nauczanie Kościoła, prace teologiczne poświęcone tematyce medialnej, a także studia specjalistyczne $\mathrm{z}$ teologii środków społecznego przekazu. To wszystko stanowi bogate źródło refleksji naukowej, obok czego trudno przejść obojętnie. W związku z tym celem tego artykułu było przyjrzenie się samemu nazewnictwu i dylematom metodologicznym odnoszących się do teologii mediów. Stąd też przeanalizowano istniejące jej definicje i wszelkie wokół niej dyskusje, badania oraz kierunek dalszych działań proponowany przez Kościół w dokumentach soborowych i posoborowych. Analiza podjętego zagadnienia miała głównie za zadanie zebrać i usystematyzować dotychczasowe podejście do teologii mediów, przedstawiając problem do dyskusji. Do tego typu debat skłania również rocznica pięćdziesięciolecia soborowych dokumentów, na kanwie których powstawały kolejny. Wydarzenie to wzbudza również pytania o charakter współczesnej teologii, a także jakie w przyszłości stoją przed nią nowe zadania. Autorka wyraża nadzieje, iż do refleksji nad teologią mediów, teologią komunikacji włączą się teologowie różnych specjalności, odpowiadając na pytanie: w jaki sposób media i komunikację można badać z perspektywy teologii moralnej, dogmatycznej, pastoralnej. Wartościowa również byłaby na tym polu współpraca $\mathrm{z}$ badaczami z obszaru nauk o mediach.

${ }^{86} \mathrm{CP} 22$.

${ }^{87}$ Kongregacja ds. Wychowania Katolickiego: Wskazówki odnośnie do formacji przyszlych kapłanów w zakresie środków społecznego komunikowania. W: Kościót a środki społecznego przekazu. Red. J. C h r a p e k. Warszawa 1990 s. 228-269; zob. J. K 1 o c h, M. P r z y b y s z: Edukacja medialna $w$ seminariach duchownych. Dylematy $i$ propozycje, http://www.up.krakow.pl/ktime/ symp2012/referaty_2012_10/kloch.pdf (dostęp: 12. 04.2012). 